\title{
GAMBARAN PENYAKIT SCHISTOSOMIASIS JAPONICUM DITINJAU DARI JARAK ANTARA RUMAH ANAK YANG TERINFEKSI DENGAN DANAU LINDU
}

\author{
${ }^{1}$ Visia Vrisca \\ ${ }^{2}$ Sarah M. Warouw \\ ${ }^{2}$ Rocky Wilar \\ ${ }^{2}$ Novie H. Rampengan \\ ${ }^{1}$ Kandidat Skripsi Fakultas Kedokteran Universitas Sam Ratulangi Manado \\ ${ }^{2}$ Bagian Ilmu Kesehatan Anak Universitas Sam Ratulangi Manado \\ Email: visiavrisca@ymail.com
}

\begin{abstract}
Schistosomiasis is a chronic parasitic disease caused by blood worms (Trematodes) from Schistosoma genus. Schistosomiasis is a tropical disease that is the third most powerful in the world, after malaria and worms. And this is a major source of morbidity and mortality for developing countries. This study aims to describe the Schistosomiasis japonicum disease in terms of the distance between infected children homes with Lake Lindu. This research is a descriptive, by collecting data of stool examination results in children aged $\leq 18$ years, after it did an interview using questionnaires.

Based on the results of interviews using questionnaires showed that the distance between infected children homes with Lake Lindu did not affect the prevalence of Schistosomiasis japonicum.
\end{abstract}

Key words: Schistosomiasis japonica, Distance between infected children homes with Lake Lindu.

\begin{abstract}
Abstrak: Schistosomiasis adalah penyakit infeksi parasit kronis yang disebabkan oleh cacing darah (Trematoda) dari genus Schistosoma. Schistosomiasis termasuk dalam penyakit tropis yang paling dahsyat ketiga di dunia setelah malaria dan penyakit cacing Dan ini menjadi sumber utama morbiditas dan mortalitas bagi negara-negara yang sedang berkembang. Penelitian ini bertujuan untuk mengetahui gambaran penyakit Schistosomiasis japonicum yang ditinjau dari jarak antara rumah anak yang terinfeksi dengan Danau Lindu. Penelitian ini merupakan penelitian yang bersifat deskriptif, yaitu dengan mengumpulkan data-data hasil pemeriksaan feses pada anak-anak yang berusia $\leq 18$ tahun, setelah itu melakukan wawancara dengan menggunakan kuesioner.

Berdasarkan hasil wawancara dengan menggunakan kuesioner menunjukkan bahwa jarak antara rumah anak yang terinfeksi dengan Danau Lindu tidak mempengaruhi angka kejadian Schistosomiasis japonicum.
\end{abstract}

Kata Kunci: Schistosomiasis japonicum, Jarak antara rumah anak yang terinfeksi dengan Danau Lindu. 
Schistosomiasis adalah penyakit infeksi parasit kronis yang disebabkan oleh cacing darah (Trematoda) dari genus Schistosoma. ${ }^{1,2}$ Schistosoma berbeda dari Trematoda jenis lainnya karena mereka hidup di dalam sistem pembuluh darah dan memiliki jenis kelamin jantan dan betina yang terpisah. ${ }^{3,4}$

Ada lima spesies Schistosoma yang ditemukan pada manusia, tetapi $>90 \%$ dari semua infeksi ini hanya disebabkan oleh 3 spesies penting yaitu: Schistosoma mansoni, Schistosoma japonicum, dan Schistosoma haematobium. Dua spesies lainnya yang jarang terjadi adalah Schistosoma intercalatum dan Schistosoma mekongi. ${ }^{5}$

Schistosomiasis lazim terjadi pada daerah tropis dan sub-tropis, khususnya pada masyarakat miskin tanpa akses air minum yang aman, sanitasi, serta infrastruktur kesehatan publik yang tidak memadai. ${ }^{2}$ Setelah malaria dan penyakit cacing, schistosomiasis adalah penyakit tropis yang paling dahsyat ketiga di dunia. Ini menjadi sumber utama morbiditas dan mortalitas bagi negara-negara berkembang di Afrika, Amerika Selatan, Karibia, Timur Tengah, dan Asia. ${ }^{2}$

Schistosomiasis endemik di 76 negara dengan pendapatan rendah, di mana terjadi di daerah-daerah pedesaan dan pinggiran-pinggiran kota. ${ }^{6}$ Lebih dari 700 juta orang di dunia berisiko terkena infeksi, dengan lebih dari 207 juta orang yang terinfeksi schistosomiasis, 85\% nya tinggal di Afrika. ${ }^{7}$ Pada kasus yang terinfeksi, diperkirakan 120 milyar orang menunjukkan gejala-gejala schistosomiasis, dan 20 milyar orang memiliki komplikasi yang serius. ${ }^{2}$

Pada tahun 2011 dilaporkan oleh WHO, ada 243 juta orang memerlukan pengobatan untuk schistosomiasis, dengan jumlah orang yang dilaporkan telah dirawat untuk schistosomiasis pada tahun 2011 adalah 28,1 juta. ${ }^{2}$ Secara global, ditemukan 200.000 kematian yang dikaitkan dengan schistosomiasis per tahun. ${ }^{8}$ Variasi dalam perkiraan prevalensi tergantung pada karakter fokus dari epidemiologi. Distribusi umum mencakup wilayah yang sangat besar, terutama di Afrika, tetapi juga di Timur Tengah, Amerika Selatan dan Asia Tenggara. ${ }^{8}$

Berdasarkan latar belakang di atas maka penulis tertarik untuk melakukan penelitian tentang gambaran penyakit Schistosomiasis japonicum yang ditinjau dari jarak antara rumah anak yang terinfeksi dengan Danau Lindu.

\section{METODE PENELITIAN}

Jenis penelitian yang digunakan adalah penelitian deskriptif dengan pendekatan cross sectional. Waktu penelitian dilakukan pada bulan November sampai Desember 2013. Tempat penelitian dilakukan di Dataran Lindu Sulawesi Tengah. Populasi adalah anak-anak yang tinggal di Dataran Lindu Sulawesi Tengah. Sampel penelitian ini merupakan semua anak-anak yang tinggal di Dataran Lindu, dengan kriteria sebagai berikut: Anak-anak yang tinggal dan lahir di Dataran Lindu, Orang tua yang telah menyetujui inform consent, Anak yang berus首 18 tahun. Variabel penelitian adalah jarak antara rumah anak yang terinfeksi dengan Danau Lindu.

Pengumpulan data dilakukan dengan mengakses data hasil pemeriksaan feses pada anak-anak yang berusia $\leq 18$ tahun, kemudian menemui anak-anak yang positif S. japonicum. Untuk mengukur jarak rumah anak yang terinfeksi dengan Danau Lindu dilakukan dengan menggunakan kuesioner. Setelah itu data yang didapat dikumpulkan, dihitung, dan disajikan dalam bentuk tulisan serta table presentasi jumlah anak yang terinfeksi.

\section{HASIL}

\section{A. Data Demografik Dataran Lindu}

Dataran Lindu merupakan suatu kasawasan yang di dalamnya terdapat hutan lindung dan dikenal dengan sebutan 
Taman Nasional Lore Lindu. Di tengahtengah Dataran Lindu terbentang suatu danau yang bernama Danau Lindu dengan diameter $\pm 9 \mathrm{Km}$ untuk panjangnya dan \pm $6 \mathrm{Km}$ untuk lebarnya. Dataran Lindu memiliki empat desa yaitu desa Puroo, Langko, Tomado, dan Anca, dengan penduduk seluruhnya yang berjumlah \pm 3000 jiwa.

\section{B. Gambaran Penyakit Schistosomiasis japonicum yang Ditinjau dari Jarak Antara Rumah Anak yang Terinfeksi dengan Danau Lindu}

Tabel 1. Gambaran Penyakit Schistosomiasis japonicum yang Ditinjau dari Jarak Antara Rumah Anak yang Terinfeksi dengan Danau Lindu

\begin{tabular}{ccc}
\hline $\begin{array}{c}\text { Jarak rumah } \\
\text { dengan Danau } \\
\text { Lindu }\end{array}$ & $\begin{array}{c}\text { Jumlah anak } \\
\text { yang positif } \\
\text { S. } \text { japonicum }\end{array}$ & $\begin{array}{c}\text { Presentasi } \\
\text { Positif }\end{array}$ \\
\hline $0-50$ meter & 5 & $17,9 \%$ \\
\hline $51-100$ meter & 8 & $28,6 \%$ \\
\hline$>100$ meter & 15 & $53,5 \%$ \\
\hline
\end{tabular}

Ket. Tabel Jarak antara rumah anak yang terinfeksi dengan Danau Lindu paling banyak adalah > 100 meter. (Tabel 1)

\section{BAHASAN}

$\begin{array}{rrr}\text { Penelitian } & \text { ini diawali dengan } \\ \text { mengumpulkan } & \text { data-data } & \text { hasil }\end{array}$ pemeriksaan feses pada anak-anak yang berusia $\leq 18$ tahun, kemudian dilanjutkan dengan mendatangi anak-anak yang positif menderita schistosomiasis untuk diberikan kuesioner mengenai jarak antara rumah anak yang terinfeksi dengan Danau Lindu.

Berdasarkan hasil wawancara dengan menggunakan kuesioner didapatkan bahwa jarak antara rumah dengan Danau Lindu tidak mempengaruhi angka kejadian schistosomiasis. Hal ini berbeda dengan hasil penelitian yang dilakukan oleh Hussain, S (2013) ${ }^{9}$ di Brazil dan Afrika yang mendapatkan bahwa, angka kejadian schistosomiasis tertinggi terdapat pada masyarakat yang tinggal di dekat danau atau sungai. Hal itu dapat terjadi karena di area Danau Lindu tersebut merupakan daerah bebas keong. Di area tersebut tidak terdapat keong Oncomelania hupensis yang menjadi hospes perantara dari penyakit ini, sehingga telur cacing yang menetas sebagai mirasidium mati karena tidak menemukan inang perantara yang cocok. Fischer dkk mengatakan bahwa distribusi geografis dari schistosoma dibatasi oleh habitat dari siput ini. ${ }^{3}$ Di Dataran Lindu, siput Oncomelania hupensis ini tersebar di beberapa kawasan seperti kawasan persawahan, kawasan kebun, kawasan hutan, padang rumput atau alang-alang, tempat yang tidak terkena sinar matahari, rawa-rawa, tanah yang basah, aliran air yang tenang, bahkan kanal irigasi untuk persawahan.

\section{SIMPULAN DAN SARAN}

Berdasarkan hasil wawancara dengan menggunakan kuesioner menunjukkan bahwa jarak antara rumah anak yang terinfeksi dengan Danau Lindu tidak mempengaruhi angka kejadian Schistosomiasis japonicum.

Walaupun distribusi geografis dari schistosoma dibatasi oleh habitat dari keong Oncomelania hupensis, tetapi dengan adanya migrasi penduduk, perkembangan ekonomi, pembangunan, serta banyak nya hewan-hewan yang dapat menjadi hospes perantara dari keong ini, pemerintah harus tetap memikirkan cara agar penyakit schistosomiasis ini tidak meluas ke area lainnya.

Memberikan kesadaran kepada masyarakat untuk menjaga lingkungan tempat tinggal mereka dengan cara menjaga kebersihan dan gaya hidup sehat, sehingga lingkungan tempat mereka tinggal tidak menjadi media transmisi dari penyakit ini. 


\section{UCAPAN TERIMA KASIH}

Ucapan terima kasih disampaikan kepada Pak Pinus Maladjuna selaku penanggung jawab P2 Schisto Dataran Lindu dan kepada semua pihak yang baik secara langsung maupun tidak langsung telah menumbuhkan ide atau gagasan dalam pemikiran penulis sehingga dapat menyelesaikan artikel ini.

\section{DAFTAR PUSTAKA}

1. Andrew D. Schistosomiasis. In: Gordon C. Cook, Alimuddin L Z, editors. Manson's Tropical Diseases. 21 ed. China: Saunders Elsevier: 2009;82:1425.

2. WHO. Schistosomiasis. Fact sheet No 115; March 2013. Accessed September 18,2013.Available from: http://www.who.int/mediacentre/factsh eets/fs115/en/

3. Fischer PR, Summer AP, White CA, Jr. In: Ralph D. Feigin, James DC, Gail JDH, Sheldon L Kaplan, editors. Textbook of Pediatric Infectious Diseases. 6 ed. United States of America: Saunders Elsevier: 2009;240:3023.

4. Safar R. Parasitologi Kedokteran. Protozoologi, Helmintologi, Entomologi. 1 st ed. Bandung: CV. Yrama Widya; 2009.h: 208.
5. Zhou XN, Bergquist R, Leonardo L, Olveda R. Schistosomiasis: The Disease and its Control. 2008 September. Accessed September 18, 2013. Available from: http://www.rnas.org.cn/upload/inFile/2 008-9-25160310-Schistosomiasis.pdf

6. Weekly epidemiological record 30 April No. 18, 2010, 85, 157-164. World Health Organization. Accessed September 18, 2013. Available from: http://www.who.int/wer.

7. Chistulo L, Loverde P, Engels D. Disease Watch: Schistosomiasis. TDR Nature Reviews Microbiology. 2004; 2:12

8. Steinmann P. Epidemiology and Diagnosis of Schistosoma japonicum other helminth infections and multiparasitism in Yunan province, People's Republic of China. (dissertation). (German): University of Basel; 2008

9. Hussain S. Schistosomiasis. Medscape. March 2013. Accessed 20 Januari 2014. Available from: http://emedicine.medscape.com/article/ 228392-overview 